\title{
No association between genetic or epigenetic variation in insulin growth factors and antipsychotic- induced metabolic disturbances in a cross-sectional sample
}

Citation for published version (APA):

Moons, T., De Hert, M., Kenis, G., Viechtbauer, W., van Os, J., Gohlke, H., Claes, S., \& van Winkel, R. (2014). No association between genetic or epigenetic variation in insulin growth factors and antipsychoticinduced metabolic disturbances in a cross-sectional sample. Pharmacogenomics, 15(7), 951-962. https://doi.org/10.2217/pgs.14.46

Document status and date:

Published: 01/05/2014

DOI:

10.2217/pgs. 14.46

Document Version:

Publisher's PDF, also known as Version of record

Document license:

Taverne

Please check the document version of this publication:

- A submitted manuscript is the version of the article upon submission and before peer-review. There can be important differences between the submitted version and the official published version of record. People interested in the research are advised to contact the author for the final version of the publication, or visit the DOI to the publisher's website.

- The final author version and the galley proof are versions of the publication after peer review.

- The final published version features the final layout of the paper including the volume, issue and page numbers.

Link to publication

\footnotetext{
General rights rights.

- You may freely distribute the URL identifying the publication in the public portal. please follow below link for the End User Agreement:

www.umlib.nl/taverne-license

Take down policy

If you believe that this document breaches copyright please contact us at:

repository@maastrichtuniversity.nl

providing details and we will investigate your claim.
}

Copyright and moral rights for the publications made accessible in the public portal are retained by the authors and/or other copyright owners and it is a condition of accessing publications that users recognise and abide by the legal requirements associated with these

- Users may download and print one copy of any publication from the public portal for the purpose of private study or research.

- You may not further distribute the material or use it for any profit-making activity or commercial gain

If the publication is distributed under the terms of Article 25fa of the Dutch Copyright Act, indicated by the "Taverne" license above, 


\section{No association between genetic or epigenetic variation in insulin growth factors and antipsychotic-induced metabolic disturbances in a cross-sectional sample}

\begin{abstract}
Aim: Second-generation antipsychotics (SGA) are known to induce metabolic disturbances. Genetic pathways, such as the IGF pathway could be associated with increased metabolic syndrome (MetS). Additionally, IGF2 methylation varies as a function of environmental influences and is associated with schizophrenia and MetS. The current study aims to evaluate whether genetic and epigenetic variation in genes of the IGF pathway are associated with metabolic disturbances in patients under treatment with SGAs. Methods: Cross-sectional metabolic data from 438 patients with schizophrenia spectrum disorder was analyzed. Using the Sequenom MassARRAY iPLEX ${ }^{\text {TM }}$ platform, 27 SNPs of the IGF1 and IGF2 genes and the IGF receptors IGF1R and IGF2R were genotyped. Methylation status of seven IGF2 CpG dinucleotides was evaluated using a Sequenom MALDI-TOF spectrometer. Results \& conclusion: There was a significant association between IGF2 methylation and genotype, but no significant association between genetic or epigenetic variability and metabolic parameters in the present study.
\end{abstract}

Original submitted 28 October 2013; Revision submitted 7 March 2014

Keywords: antipsychotic $\bullet$ genetic variation $\bullet$ IGF $\bullet$ insulin growth factor

- metabolic syndrome $\bullet$ methylation $\bullet$ schizophrenia

\section{Background}

Patients treated with antipsychotics, and specifically with second-generation antipsychotics (SGA), have an increased risk for weight gain and metabolic syndrome (MetS) [1-4]. Yet, there are large differences in the extent to which these metabolic disturbances develop in individual patients. Previous research has highlighted several risk factors underlying this intraindividual variation.

A primary risk factor is the type of SGA used. SGAs vary in their liability to induce metabolic disturbances and weight gain, with clozapine and olanzapine carrying the highest risk [5-8]. Additionally, polypharmacy, which is common in the treatment of schizophrenia, increases the chance of metabolic disturbances [9-12]. A second major contributor to the risk for MetS in patients with schizophrenia is lifestyle: as a group, patients with schizophrenia have an increased prevalence of unhealthy behaviors, such as a sedentary lifestyle [13,14], unhealthy diets [15,16] and smoking [17], which are also associated with MetS.

In addition to these modifiable risk factors, a genetic predisposition may also be present. Several polymorphisms in different molecular pathways form a baseline risk for developing MetS $[18,19]$. The one-carbon metabolism pathway, in which MTHFR plays a central role, is a prominent example [20-25]. Pathways and genes that predispose patients to SGAinduced weight gain, such as MTHFR, often overlap with those that predispose healthy adults to MetS [26-28]. Polymorphisms in this gene influence the functioning of the onecarbon metabolism, a pathway that that is important for schizophrenia and for DNA methylation $[29,30]$.
Tim Moons ${ }^{*, 1}$, Marc De Hert ${ }^{2}$, Gunther Kenis ${ }^{3}$, Wolfgang Viechtbauer ${ }^{3}, \mathrm{Jim}$ van $\mathrm{Os}^{3}$, Henning Gohlke ${ }^{4}$, Stephan Claes $^{1} \&$ Ruud van Winkel ${ }^{2,3}$ 'GRASP Research Unit, University Psychiatric Centre Catholic University Leuven, Herestraat 49, 3000 Leuven, Belgium

${ }^{2}$ University Psychiatric Centre Catholic University Leuven, Leuvensesteenweg 517, 3070 Kortenberg, Belgium ${ }^{3}$ Department of Psychiatry \& Neuropsychology, EURON, South Limburg Mental Health Research \& Teaching Network, Maastricht University Medical Centre, PO Box 616, 6200 MD Maastricht, The Netherlands

${ }^{4}$ Sequenom Inc., Hamburg, Germany *Author for correspondence:

Tel.: +3227581855

Fax: +3216332640 tim.moons@uzleuven.be 
DNA methylation is one form of epigenetic modification that may be important for metabolic disturbances. Genome-wide DNA methylation has been associated with increased risk of Type 2 diabetes and MetS in the normal population [31-34]. In patients with schizophrenia, methylation of the COMT promoter was associated with physical activity and MetS in a single study [35].

Another pathway, encompassing IGF, is both of theoretical and empirical interest in the healthy population. Both IGF1 and IGF2 and their receptors, IGF1R and $I G F 2 R$, share $>50 \%$ of their sequence with insulin and the insulin receptor [36]. Thus, a functional overlap is present with crossactivations between insulin, IGF ligands and their respective receptors [37-39]. Furthermore, IGF1 directly interacts with glucose transporters [40-42] and stimulates the differentiation of preadipocytes [43,44].

IGF may also have a role in schizophrenia: circulating IGF1 levels were significantly lower in antipsychotic-naive patients with schizophrenia in comparison with healthy volunteers in a single small study [45]. After 3 months of treatment with antipsychotics, IGF1 levels increased in patients, although they were still lower than the healthy volunteers [46]. Two crosssectional studies gave conflicting results: one Taiwanese study found lower IGF levels in patients with schizophrenia treated with clozapine [47], but a Maori study using various antipsychotics was unable to find a difference in IGF1 levels [48].

Lower concentrations of IGF1 have been associated with higher BMI or the presence of MetS in several general population studies [49-52], although some studies disagree [53,54]. Similarly, genetic alterations in the IGF pathway have been associated with increased BMI, weight or body composition in the healthy population [55-58], though some conflicting reports are present $[59,60]$.

Of interest is that the IGF2 gene contains several methylation domains that can influence the expression of the protein [61]. Methylation of the well-described differentially methylated region (DMR) is influenced by genetic factors $[62,63]$, as well as by environmental stress: adults that were prenatally exposed to famine displayed decreased methylation of the IGF2 DMR, but not the H19 region [64,65]. Subjects from these same cohorts also have a higher incidence of MetS and schizophrenia, which could be suggestive of a common underlying mechanism $[66,67]$.

Given the above, the current study aimed to evaluate whether genetic and epigenetic variation in genes of the IGF pathway are associated with weight or $\mathrm{BMI}$, or MetS in patients undergoing treatment with SGAs.

\section{Methods}

Sample

All patients suffering from schizophrenia spectrum disorder treated at the university psychiatric hospital St Jozef were invited to participate in the current study. Four hundred and thirty eight in- and out-patients suffering from schizophrenia spectrum disorders provided written consent for genetic testing and testing of metabolic side effects. They are part of a naturalistic cohort of the University Psychiatric Centre of the Catholic University of Leuven, Belgium, which has been analyzed in previous publications [21-22,68-71]. All patients were taking their current antipsychotic for a period of at least 3 months.

Psychiatric diagnosis was based on Diagnostic and Statistical Manual of Mental Disorders (DSM)-IV criteria and was made by experienced psychiatrists, responsible for the treatment of the patients. DNA extraction was performed between September 2000 and July 2008, metabolic data was collected between October 2002 and November 2007 using routine tests. MetS was evaluated using the adapted Adult Treatment Panel IIIa (ATP-IIIa) criteria [72]. According to the ATP-IIIa criteria, a patient suffers from Met $S$ when at least three of the following criteria are met: waist circumference $\geq 102 \mathrm{~cm}$ in men or $\geq 88$ $\mathrm{cm}$ in women; fasting triglycerides $\geq 150 \mathrm{mg} / \mathrm{dl}$ or drug treatment for hyperlipidemia; high-density lipoprotein (HDL) below $40 \mathrm{mg} / \mathrm{dl}$ in men, $50 \mathrm{mg} / \mathrm{dl}$ in women, or undergoing drug treatment for reduced HDL-cholesterol (HDL-C); systolic blood pressure $\geq 130 \mathrm{mmHg}$, or diastolic blood pressure $\geq 85 \mathrm{mmHg}$, or undergoing treatment for hypertension; fasting glucose $\geq 100 \mathrm{mg} / \mathrm{dl}$ or undergoing drug treatment for elevated blood glucose.

The study was approved by the local hospital ethics committee and conducted in accordance with the current revision of the Helsinki declaration [73].

\section{SNP genotyping}

DNA was extracted from peripheral blood lymphocytes using a Chemagen MSM I machine (Perkin Elmer, MA, USA), using the Chemagic DNA Blood kit special reagents, as per the Chemagic DNA Blood7k drying prefilling VD090331.che protocol.

Genotyping of 27 SNPs of IGF1 (Chromsome 12), $\operatorname{IGF1R}$ (Chromosome 15), IGF2 (Chromosome 11) and IGF2R (Chrosome 6) was carried out by Sequenom Inc. (Hamburg, Germany) using iPLEX ${ }^{\mathrm{TM}}$ chemistry on a MALDI-TOF mass spectrometer, using the primers listed in Supplementary Table 1 (see www.futuremedicine.com/doi/suppl/10.2217/pgs.14.46). In total, DNA of 417 patients from the dataset were genotyped.

Genotyping of 27 SNPs in four genes resulted in a success rate of $98.8 \%$. All SNPs except rs8191859 (in $I G F 2 R)$ were in Hardy-Weinberg equilibrium ( $\mathrm{p}>0.05)$; therefore, rs8191859 was excluded from further analy- 


\section{For reprint orders, please contact: reprints@futuremedicine.com}

sis. Additionally, six SNPs (rs8191746, rs6413491, rs8191808, rs8191844, rs8191904, rs8191955) of IGF2R had a minor allele frequency below $2.5 \%$ and, therefore, lacked sufficient variation for further analysis and were thus also excluded, resulting in 21 SNPs in four genes for the analyses.

\section{Methylation analysis}

Methylation of seven CpG sites and one negative control site within the 338 bp long IGF2 DMR (NCBI build 37, Chromosome 11: 2169459-2169796) was evaluated. CpG units 8 and 9 (@57 and @60) were combined in the analysis, as they were proximal to each other. CpG 1 (@312), CpG 2 (@296), CpG 3 (@251), CpG 4 (@202), Cpg 7 (@119) and CpG 10 (@41) correspond to those investigated by Heijmans et al. [62]. An additional CpG island, CpG 56, was also verified as negative control. Figure 1 shows the localization of the IGF2 DMR and proximal genetic variation. Primers for the current experiment were designed using the EpiDESIGNER $^{\mathrm{TM}}$ software (Sequenom Inc.), based upon an amplicon previously described for this region (See Supplementary Tables 2 \& 3) [62].

Bisulfite treatment, as well as all post-PCR steps of the EpiTYPER ${ }^{\mathrm{TM}}$ protocol were performed by Sequenom Inc. under routine conditions as described in the application note by Sequenom Inc. [74]. Methylation was verified using the MALDI-TOF mass spectrometer, allowing for a quantitative estimation of DNA methylation across CpG islands. In total, DNA methylation was measured in 438 patients.

\section{Epigenetic quality measurements}

Methylation data quality was evaluated stepwise. Only CpG sites that yielded data in $>75 \%$ of the samples were retained. None of the $\mathrm{CpG}$ sites had to be excluded in this step. All CpG units were measured three-times; only samples that yielded data on $>80 \%$ of the individual measurements (excluding the negative control) were used for further analysis.

Methylation analysis was carried out three-times, after which a mean methylation value was computed: regarding the final sample, of all these single measurements 1010 (10.98\%) did not succeed (range of failed individual measurements varied from $0.61 \%$ [CpG 10] to 58.8\% [CpG 7]). The mean CpG unit methylation per sample was calculated from the remaining data, excluding all measurements with a standard deviation $\geq 5 \%$. In total, combining all quality control steps, 371 (12.1\%) CpG measurement means were excluded from further analysis. Three patients had methylation values that were outliers (z-score of $\geq|2.5|$ ) on two or more CpG units and were removed.

\section{Statistical analysis}

Before analysis, BMI and waist circumference were logarithmically transformed to obtain normally distributed variables. All regressions were perfomed with age, sex and type of antipsychotic as a priori confounders. Analysis of methylation data was performed using $\mathrm{R}$ for windows version 2.14.2 [75], with graphs generated using the ggplot 2 module version 1.6 and Hardy-Weinberg equilibrium was verified with the Hardy-Weinberg package version 1.4 [76,77]. Genotypes were recoded as the number of minor alleles $(0,1$ or 2$)$ in case of additive models. In case of a dominant model, genotypes were recoded as either 0 or 1 (dominant allele present)

For associations between metabolic outcomes (weight, BMI, waist and hip circumference, and MetS according to the ATP-IIIa criteria) and SNPs of the IGF pathway, Bonferroni corrected p-values were regarded as significant when $\mathrm{p}$-values were below $\mathrm{p}<0.00045$ (correction for $21 \times 5$ independent tests). For associations between DNA methylation and phenotype, corrected p-values were regarded as significant when $\mathrm{p}<0.0014$ (correction for $7 \times 5$ independent tests).

\section{Results}

\section{Demographics}

Demographics of the sample are summarized in Table 1. Most patients were male $(n=295,67.4 \%)$ and their average age was 35.4 (standard deviation [SD] = 11.1). Patients had an average weight of $82.03 \mathrm{~kg}$ (range: 45-137), corresponding with an average BMI of 27.1 $\mathrm{kg} / \mathrm{m}^{2}$ (range $\left.=17.1-46.4\right)$. One hundred and forty two (35.7\%) patients suffered from MetS according to ATPIIIa criteria. Most patients were of Caucasian descent $(\mathrm{n}=418,95.4 \%)$, followed by African $(\mathrm{n}=9,2.1 \%)$, Magreb $(\mathrm{n}=6,1.3 \%)$ and Asian $(\mathrm{n}=5,1.1 \%)$. In descending order, patients were treated with olanzapine $(25.6 \%)$, risperidone $(21.5 \%)$, clozapine $(16.7 \%)$, quetiapine $(9.6 \%)$, amisulpride $(6.6 \%)$, first-generation antipsychotics $(5.5 \%)$ or aripiprazole $(5.3 \%)$. Forty three $(9.8 \%)$ patients were treated with antihypertensive drugs, $47(11 \%)$ of patients took statins and ten $(2.3 \%)$ took lipid-lowering drugs.

BMI was strongly associated with age $(\beta=0.00343$, $\mathrm{SD}=0.00079, \mathrm{p}<0.001)$, and borderline associated with sex $(\beta=0.03642, \mathrm{SD}=0.01919, \mathrm{p}>0.058)$, and type of antipsychotic ( $F=1.89$, degrees of freedom $[\mathrm{df}]=6, \mathrm{p}>0.082)$. There was no significant relationship between sex, age or type of antipsychotic and genotype (all p > 0.082).

\section{Methylation}

Mean methylation across the DMR was $42.3 \%$ $(\mathrm{SD}=5.3$, range $=31.9-56.2 \%)$. Methylation at $\mathrm{CpG}$ sites 1 and 2 appeared to follow a trimodal distribution 


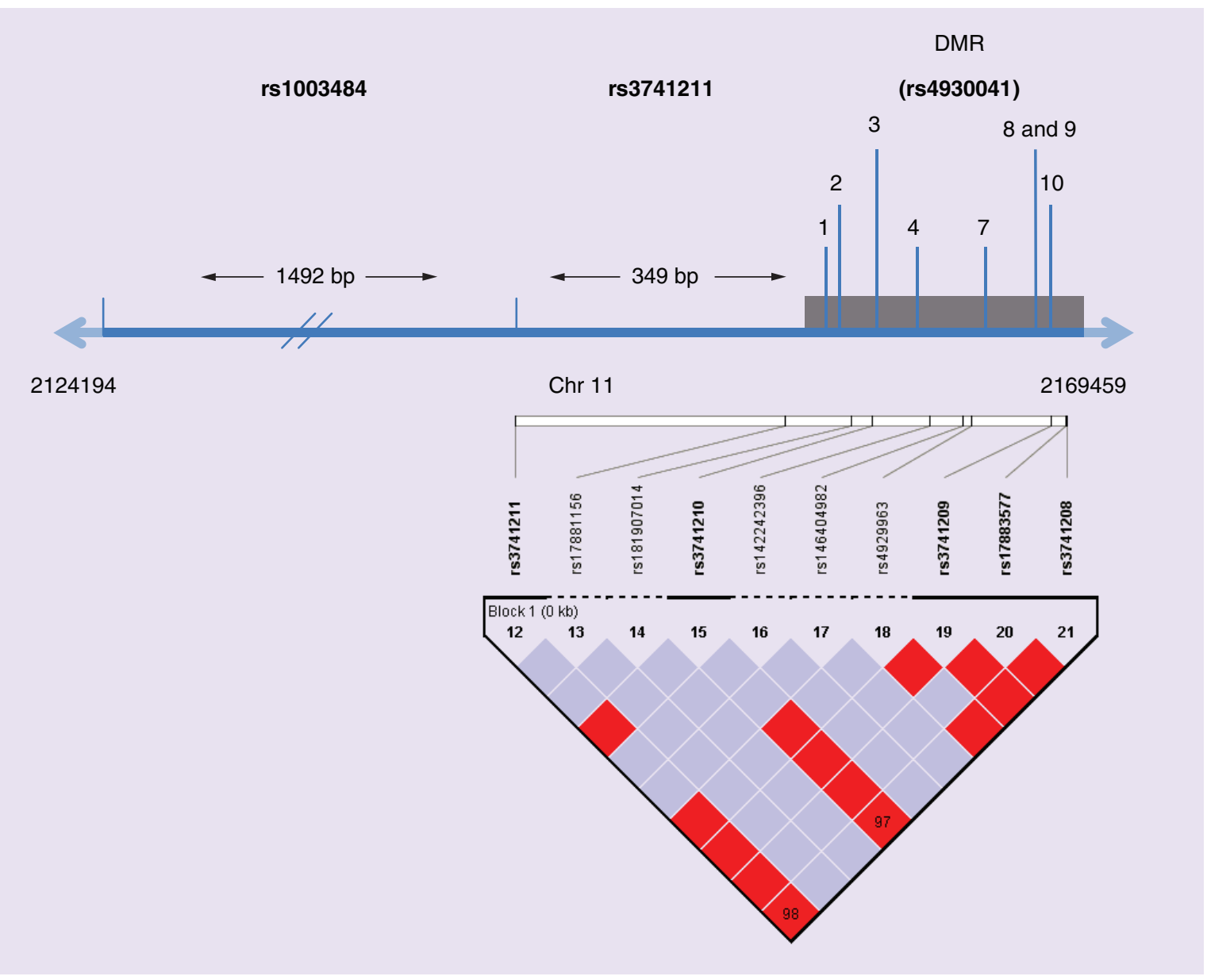

Figure 1. Localization of IGF2 genetic variation and IGF2 differentially methylated region sites. At the location of CpG 7, a SNP (rs4930041) is present, which abolishes DNA methylation in Caucasians. This SNP was not genotyped. Chr: Chromosome; DMR: Differentially methylated region.

(see Figure 2), and correlated significantly $(\mathrm{n}=344$, $\mathrm{r}=0.36, \mathrm{p}<0.001)$. All other CpG islands were approximately normally distributed. CpG 1 was significantly correlated to all other CpG islands $(|\mathrm{r}|<0.36$, $\mathrm{p}<0.003)$, CpG 2 was significantly correlated with 7 , 8-9 and 10, but not CpG 3 and 4 (data not shown).

There was no significant effect of age on mean methylation $(\mathrm{F}=1.47, \mathrm{df}=171, \mathrm{p}>0.22)$ of $\mathrm{CpG} 1-7$. Methylation of CpG 8-9 and CpG 10 decreased with age $(\mathrm{p}=0.024$ and 0.039 , respectively). Females displayed higher methylation on $\mathrm{CpG} 1(\mathrm{~F}=1.63, \mathrm{df}=1$, $\mathrm{p}=0.02)$, CpG $3(\mathrm{~F}=10.35, \mathrm{df}=1, \mathrm{p}=0.001)$ and CpG $4(\mathrm{~F}=10.18, \mathrm{df}=1, \mathrm{p}<0.002)$. There was no significant sex effect on methylation of CpG 2, CpG 7, CpG 8-9 or CpG 10 (all p > 0.2).

SNP rs3741211 of IGF2 was significantly associated with overall methylation $\left(\mathrm{F}=34.0, \mathrm{df}=3, \mathrm{p}<10^{-6}\right.$, Figure 3), with TT homozygotes having the highest methylation over the IGF2 DMR region (44.0\%), CT heterozygotes displaying intermediate methylation $(42.0 \%)$ and CC homozygotes displaying the lowest methylation (36.7\%). There was no significant effect of IGF2 rs1003484 on overall methylation across the $\operatorname{DMR}(\mathrm{F}=2.48, \mathrm{df}=2, \mathrm{p}>0.087$, Figure 4$)$. There was no effect of sex or age on IGF2 DMR methylation $(p>0.1)$.

At the level of individual CpGs in IGF2, CpG 1 was significantly associated with rs3741211 $(\mathrm{F}=23.39$, $\left.\mathrm{df}=2, \mathrm{p}<2.77 \times 10^{-10}\right)$ and $\mathrm{rs} 1003484(\mathrm{~F}=9.19$, $\mathrm{df}=2, \mathrm{p}<0.0001)$. CpG 2 was associated with rs3741211 $\left(\mathrm{F}=47.69, \mathrm{df}=2, \mathrm{p}<2.2 \times 10^{-16}\right)$, but not rs1003484. CpG 3 was associated with rs3741211 $(\mathrm{F}=7.05, \mathrm{df}=2, \mathrm{p}<0.0001)$ and $\mathrm{rs} 1003484(\mathrm{~F}=5.95$, $\mathrm{df}=2, \mathrm{p}<0.003) . \mathrm{CpG} 7$ was only associated with rs3741211 $\left(\mathrm{F}=24.6, \mathrm{df}=2, \mathrm{p}<1.48 \times 10^{-10}\right) . \mathrm{CpG}$ 8-9 was associated with $\mathrm{rs} 3741211(\mathrm{~F}=19.9, \mathrm{df}=2$, $\left.\mathrm{p}<5.82 \times 10^{-9}\right)$ and $\mathrm{rs} 1003484(\mathrm{~F}=57.31, \mathrm{df}=2$, $\left.\mathrm{p}<2.2 \times 10^{-16}\right)$. Lastly, CpG 10 was also associated with both rs3741211 $\left(\mathrm{F}=19.2, \mathrm{df}=2, \mathrm{p}<1.13 \times 10^{-}\right.$ $\left.{ }^{8}\right)$ and $\mathrm{rs} 1003484\left(\mathrm{~F}=62.12, \mathrm{df}=2, \mathrm{p}<2.2 \times 10^{-16}\right)$. None of the SNPs in IGF1, IGF1R or IGF2R were associated with methylation (data not shown). 
For reprint orders, please contact: reprints@futuremedicine.com

Table 1. Demographics of the current sample set.

\begin{tabular}{|c|c|c|c|}
\hline Variable & Total sample & Male & Female \\
\hline \multicolumn{4}{|l|}{ General } \\
\hline Age & $35.4(11.1)$ & $33.7(10.3)$ & $40.1(11.4)$ \\
\hline Male/female & 438 & 295 & 143 \\
\hline \multicolumn{4}{|l|}{ Ethnicity } \\
\hline Caucasian & $418(95.4 \%)$ & $281(95.3 \%)$ & $137(95.8 \%)$ \\
\hline African & $9(2.1 \%)$ & $5(1.7 \%)$ & $3(2.1 \%)$ \\
\hline Asian & $5(1.1 \%)$ & $2(0.7 \%)$ & $3(2.1 \%)$ \\
\hline Magreb & $6(1.4 \%)$ & $6(2.0 \%)$ & $0(0 \%)$ \\
\hline \multicolumn{4}{|l|}{ Diagnosis } \\
\hline Schizophrenia & $348(79.5 \%)$ & $184(72.4 \%)$ & $49(53.8 \%)$ \\
\hline Schizoaffective & $90(20.5 \%)$ & $70(27.6 \%)$ & $42(46.2 \%)$ \\
\hline \multicolumn{4}{|l|}{ Metabolic parameters } \\
\hline Weight & $81.9(16.3)$ & $84.5(14.8)$ & $76.9(18.5)$ \\
\hline BMI & $27.1(5.1)$ & $26.7(4.4)$ & $27.9(6.1)$ \\
\hline Waist circumference & $96.4(14.1)$ & $97.2(12.6)$ & $94.7(6.1)$ \\
\hline Hip circumference & $102.1(11.9)$ & $101.3(9.9)$ & $103.8(15.0)$ \\
\hline Metabolic syndrome $^{\dagger}$ & $142(35.7 \%)$ & $94(34.9 \%)$ & $48(37.2 \%)$ \\
\hline \multicolumn{4}{|l|}{ Main antipsychotic } \\
\hline Amisulpride & $29(6.6 \%)$ & $20(7.5 \%)$ & $9(7.0 \%)$ \\
\hline Aripiprazole & $23(5.3 \%)$ & $14(5.2 \%)$ & $9(7.0 \%)$ \\
\hline Clozapine & $73(16.7 \%)$ & $51(19.0 \%)$ & $22(17.1 \%)$ \\
\hline First generation & $24(5.5 \%)$ & $16(6.0 \%)$ & $8(6.2 \%)$ \\
\hline Olanzapine & $112(25.6 \%)$ & $77(28.6 \%)$ & $35(27.1 \%)$ \\
\hline Quetiapine & $42(9.6 \%)$ & $23(8.6 \%)$ & $19(14.7 \%)$ \\
\hline Risperidone & $94(21.5 \%)$ & $67(24.9 \%)$ & $27(20.9 \%)$ \\
\hline
\end{tabular}

Effect of genotype on metabolic parameters

No single SNP showed a significant association with any of the metabolic parameters after correcting for multiple testing (all p values > 0.01; see Supplementary Table 3). Using an additive model based on the number of minor alleles, two SNPs, rs10860861 and rs2162679 in IGF1, were associated with more than one metabolic parameter, but no association survived multiple testing correction. The first SNP, rs10860861, was associated with BMI $(n=419, \beta=-0.031$, standard error $[\mathrm{SE}]=0.012$, $\mathrm{p}=0.011)$, waist circumference $(\mathrm{n}=419, \beta=-0.020$, $\mathrm{SE}=0.0095, \mathrm{p}=0.038)$ and weight $(\mathrm{n}=419, \beta=-2.75$, $\mathrm{SE}=1.10, \mathrm{p}=0.013)$. The second $\mathrm{SNP}$ was associated with waist circumference $(n=296, \beta=0.032, S E=0.014$, $\mathrm{p}=0.028)$ and hip circumference $(\mathrm{n}=296, \beta=2.54$, $\mathrm{SE}=1.21, \mathrm{p}=0.037)$.

Using a dominant model (minor allele dominant), no association reached significance beyond the $\mathrm{p}=0.036$ level, with the strongest association between weight and rs3741211 ( $\mathrm{n}=419, \beta=-5.26, \mathrm{SE}=2.50, \mathrm{p}=0.036)$.

One SNP in IGF1 (rs10860869) was associated with MetS in the additive model ( $\mathrm{n}=420, \beta=0.422$, $\mathrm{SE}=0.180, \mathrm{p}=0.0193)$ and dominant model $(\mathrm{n}=420$, $\beta=0.422, \mathrm{SE}=0.18, \mathrm{p}=0.019)$, but these associations did not survive multiple testing. Table 2 shows the associations between individual SNPs and MetS according to ATP-IIIa criteria using the dominant model.

Effect of methylation on metabolic parameters There was a nominal significant association between CpG 4 methylation and hip circumference $(n=370$, $\beta=16.86, \mathrm{SE}=8.68, \mathrm{p}=0.0373)$; No association between methylation of any $\mathrm{CpG}$ site and metabolic parameters remained statistically significant after Bonferroni correction. No association between methylation and MetS was seen in logistic regressions. 
For reprint orders, please contact: reprints@futuremedicine.com
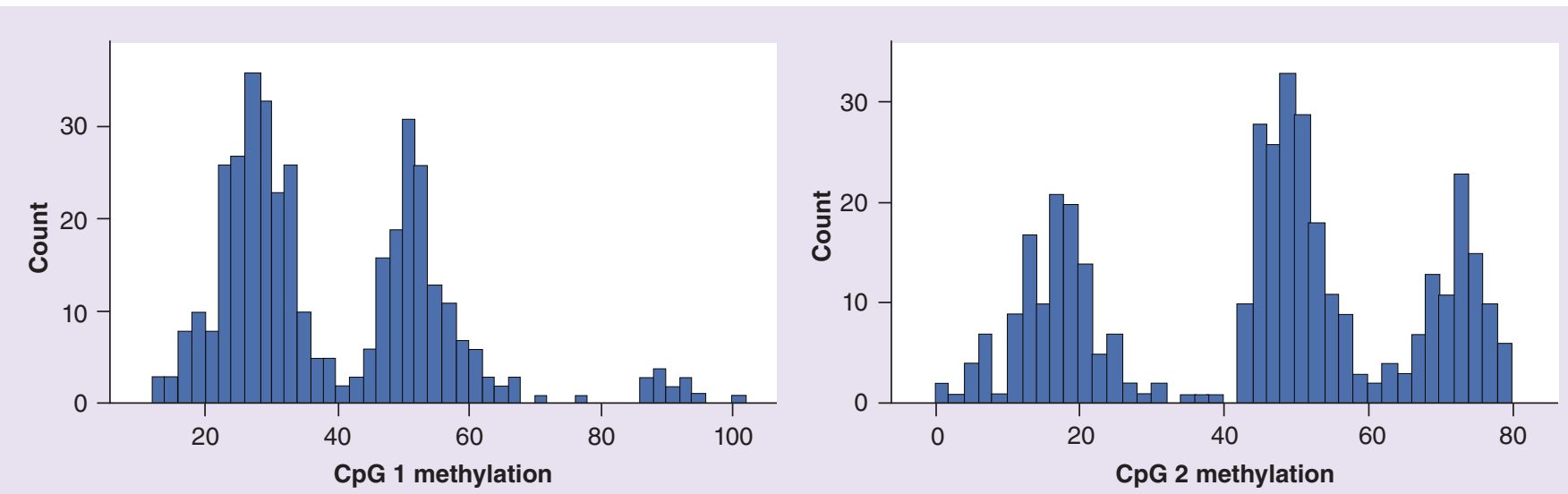

Figure 2. Histograms of CPG 1 and CPG 2, two methylation islands at the IGF2 differentially methylated region.

\section{Discussion}

To our knowledge, the current study is the first to assess the influence of IGF genotype and IGF2 DMR methylation status on metabolic disturbances in patients with schizophrenia. After correction for multiple testing, no significant association for any of the parameters was found.

\section{SNP results}

After correction for multiple testing, no association between investigated SNPs and metabolic parameters remained significant. Although several of the investigated SNPs have yielded significant associations with metabolic parameters or cardiovascular abnormalities in the general population [56,78-81], conflict- ing results are present as well $[82,83]$, and a definitive conclusion about the association between metabolic disturbances and IGF polymorphisms has not been established

\section{Methylation results}

The mean methylation (42.3\%) over the IGF2 DMR was comparable to that found in the study by Talens et al. [84], but lower than that found by Heijmans et al. $[62,64]$. The current study used one CpG island more than both previous studies and, as noted by Heijmans et al. [62], CpG 7 is at a SNP site (rs4930041) that is a T allele in Caucasians, which abolishes the CpG site and results in a high number of failed tests or $0 \%$ methylation $(77.4 \%)$ in the current sample. Without CpG 7,

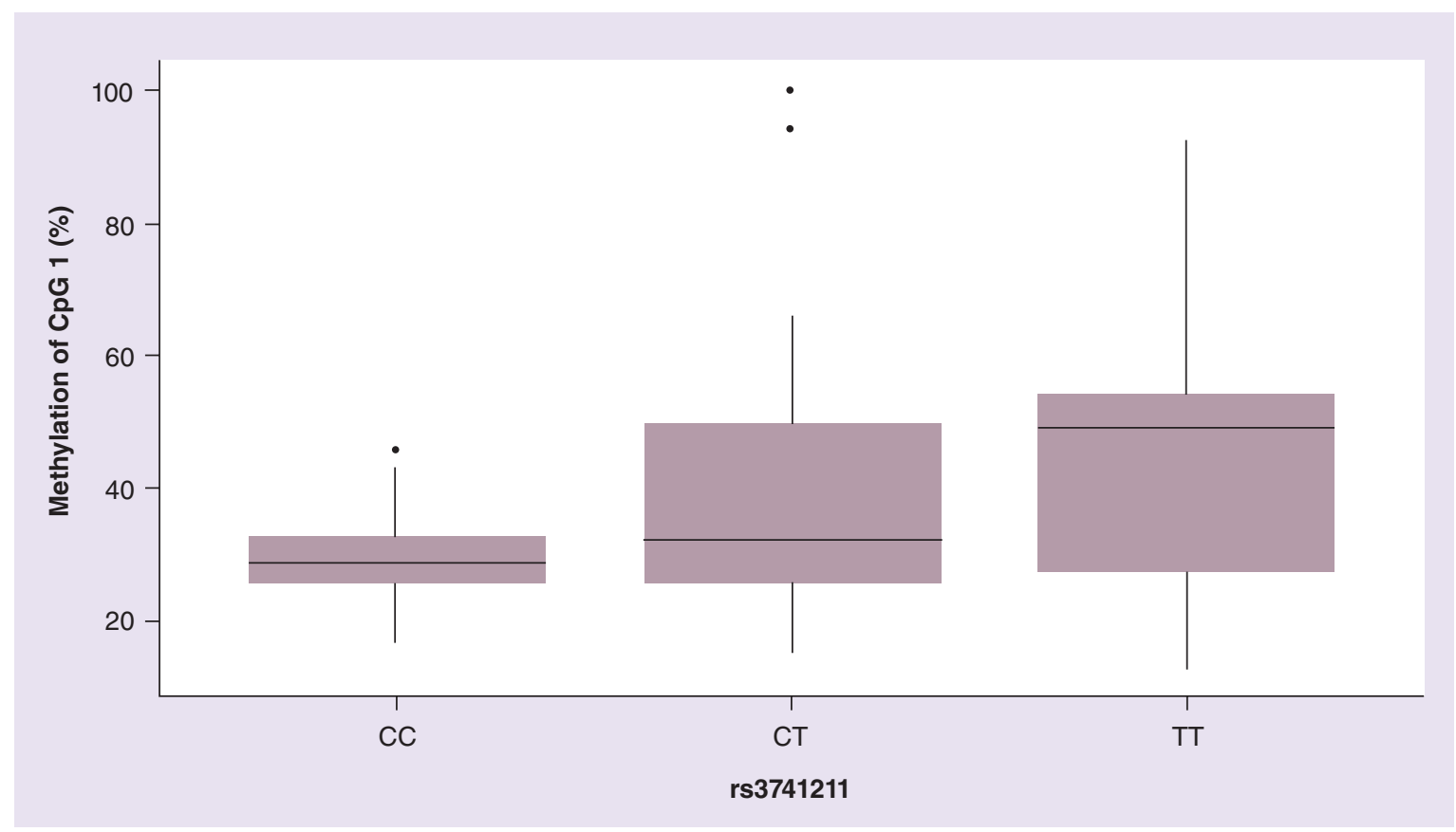

Figure 3. Influence of IGF2 rs3741211 genetic variation on mean methylation across the IGF2 differentially methylated region. Dots represent outliers. 


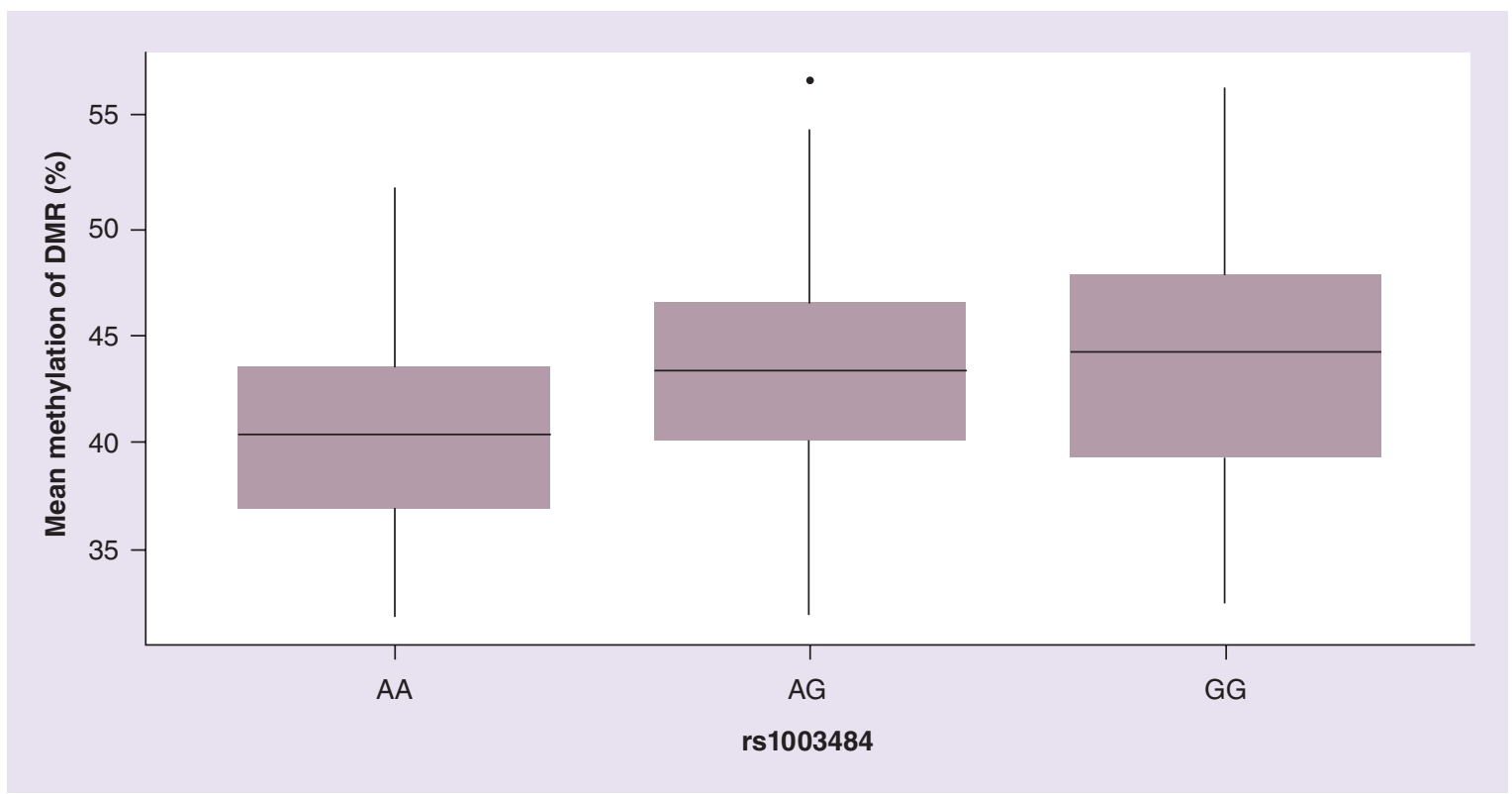

Figure 4. Influence of IGF2 rs1003484 genetic variation on mean methylation across the IGF2 differentiated region. Dots represent outliers.

DMR: Differentially methylated region.

the mean methylation across the DMR becomes 50.2\% $(S D=6.24 \%)$, in line with previously reported results. It is of note that a recent study by Melka et al. found an increase in genome-wide DNA methylation in rat brains due to olanzapine treatment [85]. In the current dataset, only CpG 1 was associated with risperidone treatment $(\beta=0.076, \mathrm{p}=0.44, \mathrm{n}=353$, uncorrected for multiple testing) and no other association reached statistical significance.

Instead of a trimodal distribution at $\mathrm{CpG} 2$ (@296), Heijmans et al. found a bimodal distribution [62]. A visual inspection of Figure 3 in their article shows a small peak between $70-75 \%$ methylation, which is more pronounced in the current study. We found a strong association between IGF2 DMR methylation and SNP rs3741211 located 349 bp upstream of the DMR. This confirms previous findings [62,63] of association between IGF2 rs3741211 and DMR methylation [63].

Currently, little is known of the exact mechanism that underlies the association between particular SNPs and DNA methylation. SNPs at methylation sites can change the cytosine in another nucleotide, abolishing the methylation site. CpG 7 is an example of this effect. Previous research in Type 2 diabetes has shown that several diabetes-associated SNPs are located at such sites [86].

Allele-specific DNA methylation is present across the whole genome and can be mediated by both $c$ is and trans acting factors [87-91], although recent genomewide mapping studies indicate that mainly cis-acting functional polymorphisms are responsible for allelespecific methylation and expression [92]. In our study, there is no evidence that $I G F 2$ methylation was influenced by SNPs within the IGF1, IGF1R or IGF2R genes, which lie on other chromosomes, suggesting that the IGF2 DMR methylation status is mainly affected by cis polymorphisms, polymorphisms that lie in or around the relevant methylation region. These cis-acting regulatory SNPs may affect downstream methylation by influencing the recruitment of the epigenetic machinery through changes in chromatin structure [92]. The current study did not assess SNPs that lie between the measured $\mathrm{CpG}$ sites within the IGF2 DMR, but as shown in Figure 1, IGF2 rs3741211 is part of a larger haplotype block comprising the DMR locus.

A primary hypothesis of the current article was that IGF2 methylation, through modulation of IGF2 expression, was associated with an increased risk of metabolic disturbances. In accordance with the finding by Heijmans et al., no association between metabolic parameters and IGF2 DMR methylation was found [62]. Although further studies should aim to confirm these findings, it is likely that the effect of IGF2 methylation on metabolic variation, if any, is small. A second possibility is that an association is only present in selected subgroups. For example, a study by Hoyo et al. did find an association between IGF2 levels and DNA methylation in newborns, but only in the subgroup of children born from obese mothers [61]. 
For reprint orders, please contact: reprints@futuremedicine.com

Table 2. Single SNP associations using a dominant model (minor allele dominant) with metabolic syndrome according to ATP-IIla criteria.

\begin{tabular}{|c|c|c|}
\hline SNP & $\begin{array}{l}\text { Odds ratio } \\
\text { (standard error) }\end{array}$ & p-value \\
\hline \multicolumn{3}{|l|}{ IGF1 } \\
\hline rs10860861 & $0.77(0.57-1.04)$ & 0.091 \\
\hline rs10860862 & $1.31(0.89-1.94)$ & 0.169 \\
\hline rs2946834 & $1.00(0.74-1.38)$ & 0.96 \\
\hline rs6214 & $0.90(0.65-1.24)$ & 0.52 \\
\hline rs1520220 & $1.08(0.75-1.57)$ & 0.67 \\
\hline rs5742694 & $1.14(0.82-1.6)$ & 0.44 \\
\hline rs978458 & $1.06(0.76-1.47)$ & 0.73 \\
\hline rs5742678 & $1.07(0.77-1.49)$ & 0.68 \\
\hline rs7136446 & $1.01(0.75-1.35)$ & 0.92 \\
\hline rs9989002 & $1.11(0.796-1.56)$ & 0.53 \\
\hline rs4764697 & $1.08(0.77-1.52)$ & 0.64 \\
\hline rs2195240 & $1.34(0.93-1.94)$ & 0.12 \\
\hline rs1019731 & $1.11(0.72-1.72)$ & 0.64 \\
\hline rs10860869 & $1.53(1.07-2.17)$ & 0.019 \\
\hline rs2162679 & $0.87(0.56-1.39)$ & 0.58 \\
\hline rs35767 & $0.82(0.55-1.23)$ & 0.35 \\
\hline \multicolumn{3}{|l|}{ IGF1R } \\
\hline rs22229765 & $0.86(0.63-1.19)$ & 0.37 \\
\hline \multicolumn{3}{|l|}{ IGF2 } \\
\hline rs1003484 & $0.80(0.58-1.12)$ & 0.20 \\
\hline rs3741211 & $0.98(0.71-1.36)$ & 0.93 \\
\hline \multicolumn{3}{|l|}{ IGF2R } \\
\hline rs8191754 & $0.86(0.54-1.38)$ & 0.54 \\
\hline
\end{tabular}

In addition, after correcting for multiple testing, the current study was unable to find any association between metabolic parameters and several SNPs within the IGF pathway. Again, the current findings may reflect those found in the general population: although IGF polymorphisms were associated in some studies with insulin sensitivity [57,79], Type 1 diabetes [58], fat tissue [55,56] or MetS [51], associations with BMI or weight were not significant in three large studies [59-60,93]. It is therefore possible that there is no true effect of genetic variation in the IGF pathway on metabolic parameters, or only a limited effect.

\section{Limitations}

Given the cross-sectional, open and naturalistic design of the current study, some limitations should be acknowledged. The first limitation is the cross- sectional design. The effect of treatment duration on DNA methylation is currently unknown. Future research should focus on prospective analysis after the start of SGAs, although in this latter case the required sample sizes are difficult to obtain. It is also of note that compared with other articles concerning metabolic disturbances in schizophrenia, the average BMI is fairly low. When comparing this study to others, this should be accounted for.

Furthermore, patients were not randomized, and it is possible that patients with worse metabolic parameters were allotted to SGAs that have less metabolic risk. No assessment of external risk factors for MetS (such as a sedentary lifestyle, smoking or diet) was available. Only peripheral blood methylation was measured, and it is possible that brain methylation patterns differ from those in peripheral blood. No history of prenatal exposure to famine, folic acid or maternal health was available, and thus no investigation of these possible confounders on IGF2 DMR methylation was carried out. Although SNPs in four genes were evaluated, only methylation of one DMR in $I G F 2$ was evaluated.

These limitations, however, are unlikely to explain the lack of reported associations within the frame of the current study.

\section{Conclusion}

Although IGFs are theorectical candidates for weight gain, and some previous research has suggested a role of genetic and epigenetic variation of IGFs in weight gain in healthy subjects, the current investigation was unable to find such an association. A significant association between SNPs in IGF2 and methylation at the DMR region was found.

Financial \& competing interests disclosure

The authors have no relevant affiliations or financial involvement with any organization or entity with a financial interest in or financial conflict with the subject matter or materials discussed in the manuscript. This includes employment, consultancies, honoraria, stock ownership or options, expert testimony, grants or patents received or pending, or royalties.

No writing assistance was utilized in the production of this manuscript.

\section{Ethical conduct of research}

The authors state that they have obtained appropriate institutional review board approval or have followed the principles outlined in the Declaration of Helsinki for all human or animal experimental investigations. In addition, for investigations involving human subjects, informed consent has been obtained from the participants involved. 


\section{Executive summary}

\section{Background}

- Treatment with second-generation antipsychotics is associated with metabolic syndrome.

- Large interindividual differences in weight gain and metabolic disturbances exist, which may be explained by genetic or epigenetic differences.

- The IGF pathway is, from a theoretical point of view, an ideal candidate to explain metabolic differences between patients.

Relationship between metabolic parameters \& IGF

- The current study was unable to find a significant association between metabolic disturbances and genetic variation in IGF genes.

- The current study was unable to find a significant association between metabolic disturbances and methylation of the IGF2 differentially methylated region.

\section{Epigenetics versus genetics}

- Epigenetic variation in IGF2 is associated with the genetic variation neighboring the differentially methylated region.

- Thus, genetic or epigenetic variation in IGFs did not have a large effect on metabolic disturbances in schizophrenia in the current study, although further research is necessary to confirm these findings.

\section{Future perspective}

- Metabolic disturbances due to antipsychotics are a major issue in the treatment of schizophrenia.

- Several genes are known to contribute to the risk of developing weight gain or metabolic syndrome. Most studies have focused on the genetic risk and little is known about the epigenetic contribution to secondgeneration antipsychotic-induced metabolic disturbances.

- In the future, we expect that more studies will focus on the combination of both epigenetic and genetic risk factors.

- With sufficient knowledge, individual risk profiles could be made, directing patients to the treatment that fits their genetic and epigenetic profile.

\section{References}

Papers of special note have been highlighted as: $\bullet$ of interest

1 De Hert M, Schreurs V, Sweers K et al. Typical and atypical antipsychotics differentially affect long-term incidence rates of the metabolic syndrome in first-episode patients with schizophrenia: a retrospective chart review. Schizophr. Res. 101(1-3), 295-303 (2008).

2 De Hert M, Detraux J, van Winkel R, Yu W, Correll CU. Metabolic and cardiovascular adverse effects associated with antipsychotic drugs. Nat. Rev. Endocrinol. 8(2), 114-126 (2011).

3 Mitchell AJ, Vancampfort D, Sweers K, van Winkel R, Yu W, De Hert M. Prevalence of metabolic syndrome and metabolic abnormalities in schizophrenia and related disorders - a systematic review and meta-analysis. Schizophr. Bull. 39(2), 306-318 (2011).

4 Mitchell AJ, Vancampfort D, De Herdt A, Yu W, De Hert $M$. Is the prevalence of metabolic syndrome and metabolic abnormalities increased in early schizophrenia? a comparative meta-analysis of first episode, untreated and treated patients. Schizophr. Bull. 39(2), 295-305 (2012).

5 Simon V, van Winkel R, De Hert M. Are weight gain and metabolic side effects of atypical antipsychotics dose dependent? A literature review. J. Clin. Psychiatry 70(7), 1041-1050 (2009).

6 Newcomer JW. Antipsychotic medications: metabolic and cardiovascular risk. J. Clin. Psychiatry 68(Suppl. 4), 8-13 (2007).
7 Rummel-Kluge C, Komossa K, Schwarz S et al. Headto-head comparisons of metabolic side effects of second generation antipsychotics in the treatment of schizophrenia: a systematic review and meta-analysis. Schizophr. Res. 123(2-3), 225-233 (2010).

8 De Hert M, Yu W, Detraux J, Sweers K, van Winkel R, Correll CU. Body weight and metabolic adverse effects of asenapine, iloperidone, lurasidone and paliperidone in the treatment of schizophrenia and bipolar disorder: a systematic review and exploratory meta-analysis. CNS Drugs 26(9), 733-759 (2012).

9 Correll CU, Frederickson AM, Kane JM, Manu P. Does antipsychotic polypharmacy increase the risk for metabolic syndrome? Schizophr. Res. 89(1-3), 91-100 (2007).

10 Huang MC, Lu ML, Tsai CJ et al. Prevalence of metabolic syndrome among patients with schizophrenia or schizoaffective disorder in Taiwan. Acta Psychiatr. Scand. 120 (4), 274-280 (2009).

11 Misawa F, Shimizu K, Fujii Y et al. Is antipsychotic polypharmacy associated with metabolic syndrome even after adjustment for lifestyle effects?: a cross-sectional study. BMC. Psychiatry 11, 118 (2011).

12 Strassnig M, Miewald J, Keshavan M, Ganguli R. Weight gain in newly diagnosed first-episode psychosis patients and healthy comparisons: one-year analysis. Schizophr. Res. 93(1-3), 90-98 (2007).

13 Vancampfort D, Probst M, Knapen J, Carraro A, De Hert M. Associations between sedentary behaviour and metabolic parameters in patients with schizophrenia. Psychiatry Res. 200(2-3), 73-78 (2012). 
14 Vancampfort D, Knapen J, Probst M, Scheewe T, Remans S, De Hert M. A systematic review of correlates of physical activity in patients with schizophrenia. Acta Psychiatr. Scand. 125(5), 352-362 (2012).

15 Strassnig M, Brar JS, Ganguli R. Dietary intake of patients with schizophrenia. Psychiatry (Edgmont) 2(2), 31-35 (2005).

16 Ellingrod VL, Taylor SF, Brook RD et al. Dietary, lifestyle and pharmacogenetic factors associated with arteriole endothelial-dependent vasodilatation in schizophrenia patients treated with atypical antipsychotics (AAPs). Schizophr. Res. 130(1-3), 20-26 (2011).

17 Bobes J, Arango C, Garcia-Garcia M, Rejas J. Healthy lifestyle habits and 10-year cardiovascular risk in schizophrenia spectrum disorders: an analysis of the impact of smoking tobacco in the CLAMORS schizophrenia cohort. Schizophr. Res. 119(1-3), 101-109 (2010).

18 Lett TA, Wallace TJ, Chowdhury NI, Tiwari AK, Kennedy JL, Muller DJ. Pharmacogenetics of antipsychotic-induced weight gain: review and clinical implications. Mol. Psychiatry 17(3), 242-266 (2011).

19 Reynolds GP, Kirk SL. Metabolic side effects of antipsychotic drug treatment--pharmacological mechanisms. Pharmacol Ther 125(1), 169-179 (2010).

20 Ellingrod VL, Miller DD, Taylor SF, Moline J, Holman T, Kerr J. Metabolic syndrome and insulin resistance in schizophrenia patients receiving antipsychotics genotyped for the methylenetetrahydrofolate reductase (MTHFR) 677C/T and 1298A/C variants. Schizophr. Res. 98(1-3), 47-54 (2008).

21 van Winkel R, Moons T, Peerbooms O et al. MTHFR genotype and differential evolution of metabolic parameters after initiation of a second generation antipsychotic: an observational study. Int. Clin. Psychopharmacol. 25(5), 270-276 (2010).

22 van Winkel R, Rutten BP, Peerbooms O, Peuskens J, van Os J, De Hert M. MTHFR and risk of metabolic syndrome in patients with schizophrenia. Schizophr. Res. 121(1-3), 193-198 (2010).

23 Ellingrod VL, Taylor SF, Dalack G et al. Risk factors associated with metabolic syndrome in bipolar and schizophrenia subjects treated with antipsychotics: the role of folate pharmacogenetics. J. Clin. Psychopharmacol. 32(2), 261-265 (2012).

24 Kuzman MR, Muller DJ. Association of the MTHFR gene with antipsychotic-induced metabolic abnormalities in patients with schizophrenia. Pharmacogenomics. 13(8), 843-846 (2012).

25 Devlin AM, Ngai YF, Ronsley R, Panagiotopoulos C. Cardiometabolic risk and the MTHFR C677T variant in children treated with second-generation antipsychotics. Transl. Psychiatry 2, e71 (2012).

26 Vattikuti S, Guo J, Chow CC. Heritability and genetic correlations explained by common SNPs for metabolic syndrome traits. PLoS Genet. 8(3), e1002637 (2012).

27 Vasilopoulos Y, Sarafidou T, Bagiatis V et al. Association between polymorphisms in MTHFR and APOA5 and metabolic syndrome in the Greek population. Genet. Test. Mol. Biomarkers 15(9), 613-617 (2011).
28 Zeman M, Jachymova M, Jirak R et al. Polymorphisms of genes for brain-derived neurotrophic factor, methylenetetrahydrofolate reductase, tyrosine hydroxylase, and endothelial nitric oxide synthase in depression and metabolic syndrome. Folia Biol. (Praha) 56(1), 19-26 (2010).

29 Burghardt KJ, Pilsner JR, Bly MJ, Ellingrod VL. DNA methylation in schizophrenia subjects: gender and MTHFR 677C/T genotype differences. Epigenomics 4(3), 261-268 (2012).

30 Misiak B, Frydecka D, Piotrowski P, Kiejna A. The multidimensional nature of metabolic syndrome in schizophrenia: lessons from studies of one-carbon metabolism and DNA methylation. Epigenomics 5(3), 317-329 (2013).

31 Barres R, Zierath JR. DNA methylation in metabolic disorders. Am. J. Clin. Nutr. 93(4), 897S-900S (2011).

32 Huang RC, Galati JC, Burrows $S$ et al. DNA methylation of the IGF2/H19 imprinting control region and adiposity distribution in young adults. Clin. Epigenetics 4(1), 21 (2012).

33 Luttmer R, Spijkerman AM, Kok RM et al. Metabolic syndrome components are associated with DNA hypomethylation. Obes. Res. Clin. Pract. 7(2), e106-e115 (2013).

34 Piyathilake CJ, Badiga S, Alvarez RD, Partridge EE, Johanning GL. A lower degree of PBMC L1 methylation is associated with excess body weight and higher HOMA-IR in the presence of lower concentrations of plasma folate. PLoS ONE 8(1), e54544 (2013).

35 Lott SA, Burghardt PR, Burghardt KJ, Bly MJ, Grove TB, Ellingrod VL. The influence of metabolic syndrome, physical activity and genotype on catechol- $O$-methyl transferase promoter-region methylation in schizophrenia. Pharmacogenomics J. 13(3), 264-271 (2013).

36 Stewart CE, Rotwein P. Growth, differentiation, and survival: multiple physiological functions for insulin-like growth factors. Physiol. Rev. 76(4), 1005-1026 (1996).

37 Conti E, Carrozza C, Capoluongo E et al. Insulin-like growth factor- 1 as a vascular protective factor. Circulation 110(15), 2260-2265 (2004).

38 Oliveira CR, Meneguz-Moreno RA, Aguiar-Oliveira MH, Barreto-Filho JA. Emerging role of the GH/IGF-I on cardiometabolic control. Arq Bras. Cardiol. 97(5), 434-439 (2011).

39 Akanji AO, Smith RJ. The insulin-like growth factor system, metabolic syndrome, and cardiovascular disease risk. Metab. Syndr. Relat. Disord. 10(1), 3-13 (2012).

40 Di Cola G, Cool MH, Accili D. Hypoglycemic effect of insulin-like growth factor-1 in mice lacking insulin receptors. J. Clin. Invest. 99(10), 2538-2544 (1997).

41 Cheng CM, Reinhardt RR, Lee WH, Joncas G, Patel SC, Bondy CA. Insulin-like growth factor 1 regulates developing brain glucose metabolism. Proc. Natl Acad. Sci USA 97(18), 10236-10241 (2000).

42 Zhou J, Bievre M, Bondy CA. Reduced GLUT1 expression in Igf1 $1^{-1-}$ null oocytes and follicles. Growth Horm. IGF. Res 10(3), 111-117 (2000). 


\section{For reprint orders, please contact: reprints@futuremedicine.com}

43 Scavo LM, Karas M, Murray M, Leroith D. Insulin-like growth factor-I stimulates both cell growth and lipogenesis during differentiation of human mesenchymal stem cells into adipocytes. J. Clin. Endocrinol. Metab. 89(7), 3543-3553 (2004).

44 Dos Santos E, Dieudonne MN, Leneveu MC et al. Effects of 17 beta-estradiol on preadipocyte proliferation in human adipose tissue: Involvement of IGF1-R signaling. Horm. Metab. Res. 42(7), 514-520 (2010).

45 Venkatasubramanian G, Chittiprol S, Neelakantachar N et al. Insulin and insulin-like growth factor-1 abnormalities in antipsychotic-naive schizophrenia. Am. J. Psychiatry 164(10), 1557-1560 (2007).

- Showed that drug-naive patients with schizophrenia have higher plasma insulin levels and lower IGF-1 levels, although the study is limited by a small sample size.

46 Venkatasubramanian G, Chittiprol S, Neelakantachar N, Shetty T, Gangadhar BN. Effect of antipsychotic treatment on insulin-like growth factor-1 and cortisol in schizophrenia: a longitudinal study. Schizophr. Res. 119(1-3), 131-137 (2010).

47 Wu MK, Huang CY, Liou YJ, Wang CK, Lee SD. Glucoseinsulin homeostasis, lipid profiles and GH-IGF-IGFBP axis in clozapine-treated schizophrenic obesity versus nonpsychiatric obesity. Int. J. Obes. (Lond.) 32(3), 436-442 (2008).

48 Poa NR, Edgar PF. Insulin resistance is associated with hypercortisolemia in Polynesian patients treated with antipsychotic medication. Diabetes Care 30 (6), 1425-1429 (2007).

49 Succurro E, Arturi F, Grembiale A et al. Positive association between plasma IGF1 and high-density lipoprotein cholesterol levels in adult nondiabetic subjects. Eur. J. Endocrinol. 163(1), 75-80 (2010).

50 Savastano S, Di SC, Pizza G et al. Liver-spleen axis, insulinlike growth factor-(IGF)-I axis and fat mass in overweight/ obese females. J. Transl. Med. 9, 136 (2011).

51 Mora M, Perales MJ, Serra-Prat M et al. Aging phenotype and its relationship with IGF-I gene promoter polymorphisms in elderly people living in Catalonia. Growth Horm. IGF. Res 21(3), 174-180 (2011).

52 Oh J, Kim JY, Park S et al. The relationship between insulinlike growth factor- 1 and metabolic syndrome, independent of adiponectin. Clin. Chim. Acta 413(3-4), 506-510 (2012).

53 Fowke JH, Matthews CE, Yu H et al. Racial differences in the association between body mass index and serum IGF1, IGF2, and IGFBP3. Endocr. Relat Cancer 17(1), 51-60 (2010).

54 Kreitschmann-Andermahr I, Suarez P, Jennings R, Evers N, Brabant G. GH/IGF-I regulation in obesity - mechanisms and practical consequences in children and adults. Horm. Res. Paediatr. 73(3), 153-160 (2010).

55 Fehringer G, Ozcelik H, Knight JA, Paterson AD, Boyd NF. Association between IGF1 CA microsatellites and mammographic density, anthropometric measures, and circulating IGF-I levels in premenopausal Caucasian women. Breast Cancer Res. Treat. 116(2), 413-423 (2009).
56 Kostek MC, Devaney JM, Gordish-Dressman $\mathrm{H}$ et al. A polymorphism near IGF1 is associated with body composition and muscle function in women from the Health, Aging, and Body Composition study. Eur. J. Appl. Physiol. $110(2), 315-324$ (2010).

57 Sookoian S, Gianotti TF, Gemma C, Burgueno AL, Pirola CJ. Role of genetic variation in insulin-like growth factor 1 receptor on insulin resistance and arterial hypertension. J. Hypertens. 28(6), 1194-1202 (2010).

58 Concannon P, Onengut-Gumuscu S, Todd JA et al. A human type 1 diabetes susceptibility locus maps to chromosome 21q22.3. Diabetes 57(10), 2858-2861 (2008).

59 Slattery ML, Murtaugh M, Caan B, Ma KN, Neuhausen S, Samowitz W. Energy balance, insulin-related genes and risk of colon and rectal cancer. Int. J. Cancer 115(1), 148-154 (2005).

60 Fehringer G, Ozcelik H, Knight JA et al. Family-based association study of IGF1 microsatellites and height, weight, and body mass index. J. Hum. Genet. 55(4), 255-258 (2010).

61 Hoyo C, Fortner K, Murtha AP et al. Association of cord blood methylation fractions at imprinted insulin-like growth factor 2 (IGF2), plasma IGF2, and birth weight. Cancer Causes Control. 23(4), 635-645 (2012).

62 Heijmans BT, Kremer D, Tobi EW, Boomsma DI, Slagboom PE. Heritable rather than age-related environmental and stochastic factors dominate variation in DNA methylation of the human IGF2/H19 locus. Hum. Mol. Genet. 16(5), 547-554 (2007).

63 Tobi EW, Slagboom PE, van DJ et al. Prenatal famine and genetic variation are independently and additively associated with DNA methylation at regulatory loci within IGF2/H19. PLoS ONE 7(5), e37933 (2012).

64 Heijmans BT, Tobi EW, Stein AD et al. Persistent epigenetic differences associated with prenatal exposure to famine in humans. Proc. Natl Acad. Sci. USA 105(44), 17046-17049 (2008).

65 Tobi EW, Lumey LH, Talens RP et al. DNA methylation differences after exposure to prenatal famine are common and timing- and sex-specific. Hum. Mol. Genet. 18(21), 4046-4053 (2009).

66 Fall $\mathrm{CH}$. Evidence for the intra-uterine programming of adiposity in later life. Ann. Hum. Biol. 38(4), 410-428 (2011).

67 Lumey LH, Stein AD, Susser E. Prenatal famine and adult health. Annu. Rev. Public Health 32, 237-262 (2011).

68 De Hert M, van Winkel R, Van Eyck D et al. Prevalence of diabetes, metabolic syndrome and metabolic abnormalities in schizophrenia over the course of the illness: a cross-sectional study. Clin. Pract. Epidemiol. Ment. Health 2, 14 (2006).

69 van Winkel R, van Os J, Celic I et al. Psychiatric diagnosis as an independent risk factor for metabolic disturbances: results from a comprehensive, naturalistic screening program. J. Clin. Psychiatry 69 (8), 1319-1327 (2008).

70 Moons T, Claes S, Martens GJ et al. Clock genes and body composition in patients with schizophrenia under treatment with antipsychotic drugs. Schizophr. Res. 125(2-3), 187-193 (2011). 


\section{For reprint orders, please contact: reprints@futuremedicine.com}

71 Yu W, De Hert M, Moons T, Claes S, Correll CU, van Winkel R. CNR1 gene and risk of the metabolic syndrome in patients with schizophrenia. J. Clin. Psychopharmacol. 33(2), 186-192 (2012).

72 Grundy SM, Cleeman JI, Daniels SR et al. Diagnosis and management of the metabolic syndrome: an American Heart Association/National Heart, Lung, and Blood Institute Scientific Statement. Circulation 112(17), 2735-2752 (2005).

73 WMA Declaration of Helsinki - Ethical Principles for Medical Research Involving Human Subjects (2008). www.wma.net/en/30publications/10policies/b3

74 Ehrich M, Correll D, van den Boom D. Introduction to EpiTYPER for quantitative DNA methylation analysis using the MassARRAY ${ }^{\circledR}$ System. Sequenom Application Note (1), 18 (2006).

75 R Development Core Team. R. A language and environment for statistical computing. In: R Foundation for Statistical Computing. R Development Core Team, Vienna, Austria (2014). www.R-project.org

76 Wickham H. ggplot2: Elegant Graphics For Data Analysis. Springer, NY, USA (2009).

77 Graffelman J, Camarena JM. Graphical tests for HardyWeinberg equilibrium based on the ternary plot. Hum. Hered. 65(2), 77-84 (2008).

78 Cheng J, Liu J, Li X et al. Insulin-like growth factor-1 receptor polymorphism and ischemic stroke: a case-control study in Chinese population. Acta Neurol. Scand. 118(5), 333-338 (2008).

79 Hu C, Zhang R, Wang C et al. Variants from GIPR, TCF7L2, DGKB, MADD, CRY2, GLIS3, PROX1, SLC30A8 and $I G F 1$ are associated with glucose metabolism in the Chinese. PLoS ONE 5(11), e15542 (2010).

80 Huuskonen A, Lappalainen J, Oksala N et al. Common genetic variation in the $I G F 1$ associates with maximal force output. Med. Sci. Sports Exerc. 43(12), 2368-2374 (2011).

81 Mannino GC, Greco A, De LC et al. A fasting insulinraising allele at $I G F 1$ locus is associated with circulating levels of IGF-1 and insulin sensitivity. PLoS ONE 8(12), e85483 (2013).

82 Tekcan D, Bas F, Atalar F et al. No effect of the IGF-1 gene rs35767 and rs17032362 polymorphisms in the etiology of idiopathic short stature. Exp. Clin. Endocrinol. Diabetes 120 (7), 395-400 (2012).

83 Fujita H, Hara K, Shojima N et al. Variations with modest effects have an important role in the genetic background of Type 2 diabetes and diabetes-related traits. J. Hum. Genet. 57(12), 776-779 (2012).

84 Talens RP, Christensen K, Putter $\mathrm{H}$ et al. Epigenetic variation during the adult lifespan: cross-sectional and longitudinal data on monozygotic twin pairs. Aging Cell 11(4), 694-703 (2012).

85 Melka MG, Laufer BI, McDonald P et al. The effects of olanzapine on genome-wide DNA methylation in the hippocampus and cerebellum. Clin. Epigenetics 6(1), 1 (2014).

- Found a genome-wide methylation change in rats treated with olanzapine.

86 Dayeh TA, Olsson AH, Volkov P, Almgren P, Rönn T, Ling C. Identification of CpG-SNPs associated with Type 2 diabetes and differential DNA methylation in human pancreatic islets. Diabetologia 56(5), 1036-1046 (2013).

87 Kerkel K, Spadola A, Yuan E et al. Genomic surveys by methylation-sensitive SNP analysis identify sequencedependent allele-specific DNA methylation. Nat. Genetics 40(7), 904-908 (2008).

88 Zhang D, Cheng L, Badner JA et al. Genetic control of individual differences in gene-specific methylation in human brain. Am. J. Hum. Genet. 86(3), 411-419 (2010).

89 Bell JT, Pai AA, Pickrell JK et al. DNA methylation patterns associate with genetic and gene expression variation in HapMap cell lines. Genome Biol. 12(1), R10 (2011).

90 Docherty S. A genetic association study of DNA methylation levels in the DRD4 gene region finds associations with nearby SNP. Behav. Brain Funct. 8(1), 31 (2012).

91 Zhang Y, Rohde C, Tierling S. DNA methylation analysis of chromosome 21 gene promoters at single base pair and single allele resolution. PLoS Genetics 5(3), e1000438 (2009).

92 Tycko B. Allele-specific DNA methylation: beyond imprinting. Hum. Mol. Genet. 19(R2), R210-R220 (2010).

93 Souren NY, Zeegers MP, Janssen RG et al. Anthropometry, carbohydrate and lipid metabolism in the East Flanders Prospective Twin Survey: linkage of candidate genes using two sib-pair based variance components analyses. Twin. Res. Hum. Genet. 11(5), 505-516 (2008). 